\title{
Pediatric Oncology Group
}

National Cancer Institute

\section{Source}

National Cancer Institute. Pediatric Oncology Group. NCI Thesaurus. Code C19776.

An $\mathrm{NCl}$-sponsored clinical trials cooperative group of individuals and institutions dedicated to controlling cancer among children and adolescents. 